\title{
Board Engagement in IT Governance: Opening Up the Black Box of IT Oversight Committees at Board Level
}

\author{
Laura Caluwe \\ University of Antwerp - Antwerp Management \\ School, \\ Antwerp, Belgium \\ Laura.caluwe@uantwerpen.be
}

\author{
Steven De Haes \\ University of Antwerp - Antwerp Management \\ School, \\ Antwerp, Belgium \\ Steven.dehaes@uantwerpen.be
}

\begin{abstract}
Researchers and practitioners seem to agree on the importance of boards of directors engaging in IT governance. Yet, only a minority of boards around the globe are taking up accountability for governing IT, pointing towards a knowing-doing gap. Efforts have been made to close this gap by creating implementation guidelines for this type of engagement. One of the most frequently mentioned guidelines is the implementation of an IT oversight or similar committee at board level. However, research shows that few boards have established such a committee, which might be caused by the lack of detailed guidance on the workings and role of such committees. This paper discusses the case of the University of Antwerp that has established two IT oversight committees at board level. We demonstrate how IT oversight committees can be established and how they fit into the role of the board with regard to IT governance.
\end{abstract}

\section{Introduction}

Organizations are becoming increasingly dependent on IT for both innovation and operations. As a consequence, IT should become a part of strategy and risk discussions. As the boards' responsibilities entail both strategy and risk management, we argue that boards can no longer fully delegate IT-related strategic decision making and control. Indeed, more and more research calls for engagement of the board of directors in IT governance $[4,13,27]$. At the same time, research shows that few boards take up accountability for governing IT $[3,4,7,28]$. Hence, there seems to be a knowing-doing gap, suggesting that boards are struggling with the implementation of their IT governance duties. Some research efforts have been done towards closing this gap by presenting implementation guidelines.

One of the most frequently mentioned guidelines is the implementation of an IT oversight (or similar) committee at the level of the board $[8,17,18,21,22$, 26]. Yet, this recommendation does not seem to find its way to practice $[3,7,13]$. Therefore, a clear discrepancy exists between the recommendations provided by academics and the current state of practice. We found that even though IT oversight committees are the most frequently mentioned IT governance practice at the level of the board in academic research, little is said about the role and the workings of such a committee. That is, current research remains quite superficial. With this paper, we aim to contribute to the IT governance knowledge base by providing an example of how an organization, the University of Antwerp, has implemented an IT oversight committee and how this committee relates to the role of the board with regard to IT governance. Hence, our study is guided by the following two research questions:

RQ1: Which role(s) can an IT oversight (or similar) committee at the level of the board of directors assume?

RQ2: How can an IT oversight (or similar) committee at the level of the board of directors be organized?

The remainder of this proceedings paper is structured as follows. First, a short description is provided on board level IT governance as well as an overview of the theories that are mentioned in the relating literature. Next, a summary of the literature on IT oversight (or similar) committees at the level of the board is presented. Third, the case of the University of Antwerp is described, shedding light on the specifics of an IT oversight committee. The paper ends with a discussion of what we can learn from the University of Antwerp case, a conclusion and some 
limitations of this research and suggestions for future research.

\section{Board level IT governance}

IT governance, otherwise referred to as "enterprise governance of IT" or "corporate governance of IT", is "an integral part of corporate governance, exercised by the Board, overseeing the definition and implementation of processes, structures and relational mechanisms in the organization that enable both business and IT people to execute their responsibilities in support of business/IT alignment and the creation of business value from IT-enabled investments" [10, 11]. This definition explicitly positions IT governance as a responsibility of the board of directors. This focus on the role of the board in IT governance is relatively new. Previously, IT governance research mainly focused on the IT decision-making structures at managerial-level and the contingencies that determine the best way to implement IT governance $[6,9,30]$. Recently, the role of the board in ITrelated strategic decision-making and control has gained attention.

With regard to theoretical justification of IT governance at the level of the board, agency theory is the most widely used theoretical perspective $[5,16$, $20,31]$. This agency theory approach implies a focus on the control function of the board regarding IT. Some researchers use the resource-based view of the firm [26, 28] and the resource dependence theory [27, 31] as a perspective to examine board level IT governance, considering boards and board members as potentially valuable resources for governing IT. Others suggest there is no one best way to implement or shape board level IT governance, building on contingency theory [4, 26, 27]. Similarly, Jewer and McKay [13] combine institutional and strategic choice theory to examine the antecedents and consequences of board level IT governance. They argue that the involvement of the board in IT governance depends on institutional pressures that influence the organization and the strategic choices made by the board itself. Others build on stewardship theory [26, 27], suggesting that managers are trustworthy stewards of the organization and they are in need of advice from the board of directors. Lastly, stakeholder theory is mentioned in board level IT governance research, implying that the board is responsible for the oversight of the main IT resources in support of all organization stakeholders [5]. These different theoretical paradigms imply several board roles regarding IT governance. That is, the board has a control, service and resource dependence role with regard to governing IT, as is proposed in corporate governance literature [14]. Furthermore, the engagement of the board in IT governance depends on several factors, including institutional pressures and board decisions.

\section{IT oversight (or similar) committees at the level of the board of directors}

The most frequently mentioned approach to increase board involvement in IT governance is the establishment of an IT oversight or similar committee at board level $[8,17,18,21,22,26]$. Different authors use different terms to refer to such a committee; IT oversight committee [8, 17, 21], IT governance committee $[17,18]$, IT steering committee [22] and IT committee [26].

Various committee responsibilities are mentioned in academic literature. Nolan and McFarlan [17] argue that an IT oversight committee is responsible for watching out for what competitors and other organizations are doing with technology. On the other hand, Oliver and Walker's research [18] addresses the topic of software development projects and posits that the IT oversight committee is a body responsible for governing: "expenditure and realization of benefits of current and future IT investments", "standards, risk and compliance" and "performance". Posthumus, von Solms [21] argue that the IT oversight committee should ensure that IT is systematically added to the board's agenda and that it is addressed through a structured approach. Moreover, it is the committee's responsibility to make sure that the board possesses all information necessary for IT-related decision-making.

Despite the advice of these studies to establish a board level IT oversight or similar committee, research points out that the occurrence of these committees in practice is rather low [3, 7, 13]. Figures ranging from $74.5 \%$ [3] to $91 \%$ [13] of survey respondents that indicate not having such a committee. On top of that, interviews with practitioners show that some are not at all in favor of introducing such a committee, because of time constraints or because they do not believe that boards have the appropriate expertise [3, 13]. Coertze and Von Solms [7] warn for the pitfalls of establishing a committee at board level. They emphasize that even though a committee is established, the board still remains accountable.

A contingency approach can be taken with regard to the implementation of an IT oversight or similar committee. Such a committee is not suited for every type of organization. The need depends on the role of 
IT in the organization $[8,17,21]$. An important framework that can be used to describe the role of IT in the organization is the strategic impact grid developed by Nolan and McFarlan [17]. They posit that organizations can either have a defensive IT strategy, which focuses on operational reliability, ensuring smoothly running, secure, cost-effective IT systems or an offensive IT strategy, which considers IT as a strategic asset, enabling the organization to offer new products and services or to be more responsive to customer needs. Accordingly, the strategic impact grid which identifies four "IT use modes" based on the organization's need for reliable IT and it's need for new IT. Organizations in support mode only need technology to support employee's activities. Factory mode organizations require highly reliable IT, but have a low need for new IT. When the need for new IT is high, but the organization does not rely on IT for the continuity of the business, turnaround mode applies. Organizations with a high need for both reliable and new IT are situated in the strategic mode.

A similar perspective is used by Coertze and von Solms [8], who build on this notion of defensive and offensive IT strategy. They propose the idea of an IT alignment continuum that includes the organization's IT dependency ranging from a defensive stance, where IT supports the business, to an offensive stance, where IT is the business. These researchers agree that in case of an offensive IT strategy or stance, a separate IT oversight or similar committee is required. The audit or risk management committee can take up the board level IT governance responsibilities in organizations with a defensive IT strategy or stance $[17,21]$. The IT expertise within the board is also a determining factor for the need of an IT oversight committee. Boards with a limited level of IT expertise might benefit more from establishing such a committee [8].

In case an organization chooses to implement an IT oversight or similar committee, "the appropriate members and the chairman should be selected, the group's relationship to the audit committee should be determined and the charter should be prepared". Similar to other board level committees, like an audit or compensation committee, independent directors are considered to be appropriate members. As the committee's focus is on IT, it should include at least one IT expert with profound knowledge of the business needs. The selection of the chairman depends on the role of IT in the organization. In case of support, factory or turnaround mode, the chairman should be an IT-savvy business executive. Organizations in strategic mode should appoint an IT expert as chair. Furthermore, a close relationship between the IT oversight committee and the audit committee is key. This could be facilitated by including the same person in both committees. [17]

The board level committee responsible for IT governance should regularly report to the board of directors. Posthumus, von Solms [21] specify the frequency of this reporting. More specifically, in organizations in support mode, the committee should report to the board every 6 to 12 months, while the factory mode requires a report every 3 to 6 months. The IT oversight or similar committee in organizations in an offensive mode should report to the board every 3 months. An overview of the research on IT oversight or similar committees can be found in Table 1.

\section{Table 1 Overview IT oversight or similar} committee

\begin{tabular}{|c|c|c|c|c|}
\hline \multirow{2}{*}{ 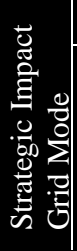 } & \multicolumn{2}{|l|}{ Defensive } & \multicolumn{2}{|l|}{ Offensive } \\
\hline & Support & Factory & Turnaround & Strategic \\
\hline 氖 & $\begin{array}{l}\text { Audit or risk } \\
\text { management } \\
\text { committee }\end{array}$ & $\begin{array}{l}\text { Audit or risk } \\
\text { management } \\
\text { committee }\end{array}$ & $\begin{array}{l}\text { IT } \\
\text { oversight } \\
\text { committee }\end{array}$ & $\begin{array}{l}\text { IT } \\
\text { oversight } \\
\text { committee }\end{array}$ \\
\hline 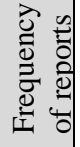 & $\begin{array}{l}\text { Every 6-12 } \\
\text { months }\end{array}$ & $\begin{array}{l}\text { Every 3-6 } \\
\text { months }\end{array}$ & $\begin{array}{l}\text { Every } 3 \\
\text { months }\end{array}$ & $\begin{array}{l}\text { Every } 3 \\
\text { months }\end{array}$ \\
\hline
\end{tabular}

\section{Research approach}

This paper describes the case of board level IT governance at the university of Antwerp. Case research perfectly fits our goal, as it is particularly relevant when the research question that is put forward seeks to explain how a social phenomenon works and requires an extensive and "in-depth" description of this phenomenon [32]. In order to truly understand the reason for the establishment of IT governance practices at the level of the board of directors and how these practices work at the University of Antwerp, multiple data sources were combined. Five stakeholders were interviewed using a semi-structured interview protocol: the rector, the chair of the board of administration, the two heads of the IT department and the head of the department of research and innovation. These stakeholders were actively involved in the establishment of the new IT governance practices. The interviews were conducted 
in February, March and April of 2017 at the University of Antwerp. The interviews were recorded and transcribed to facilitate their processing. In addition, documents such as the meeting minutes of the board and the IT governance committee were examined.

\section{The case of the University of Antwerp}

In this section, the case of the University of Antwerp will be described. First, an introduction on the university and its top-level entities is provided. Second, the board level IT governance initiatives at the university are presented.

\subsection{Introduction to the case}

The University of Antwerp is a relatively young university, founded in 2003, fusing three separate university institutions that date back to 1965 . Currently the university is responsible for the education of 20,367 students of 116 nationalities. The university staff consists of 5,398 people, including professors, assistants, researchers, education staff and administrative and technical staff. Its three core tasks are research, education and services.

The central governance structure at the University of Antwerp consists of the rector, 3 central governing bodies and 9 central advisory bodies. The rector is the university's highest academic official. He is appointed for a four-year term by the board of directors after university-wide elections. The central governing bodies include the board of directors, the executive board and the board of administration, which is responsible for the daily management of the university. These governing bodies are supported by the central advisory bodies, including the education board, the research board and the academic council for service to society.

The IT department of the University of Antwerp maintains, manages and develops the IT infrastructure at the university. They provide solutions to support the three core tasks of the university: research, education and services, but also facilitate secondary processes such as administration and management. In addition, they provide direct support to end users and attend to the maintenance of the infrastructure.

\subsection{Board level IT governance at the University of Antwerp}

Like many organizations, the University of Antwerp has become increasingly dependent on IT. This increasing dependence on IT also entails a growing number of IT enabled investments that need to be carried out by the IT department. The IT department began to struggle with this great number of IT enabled investments. No central business forum existed to decide which projects would be executed and which would not, swamping the IT department with many requests they could not deliver against. This situation often led to frustration on the business side, a tension which was also reported to and known by some board members.

Furthermore, in 2016, a new rector came at the head of the University of Antwerp. The newly appointed rector strongly believes that the organization should think about long term developments and how the university can adapt to these developments. More specifically, he stated that he thinks it is the task of the board of directors to create this long term vision, also regarding IT-related issues.

Accordingly, the University of Antwerp decided to tackle the need to (1) establish a more formal IT portfolio management process that includes all relevant stakeholders, (2) increase the involvement of the board in this process and (3) ensure a more forward-looking approach.

A widely acknowledged strategy to increase and improve the involvement of the board in IT-related decision making and control, is to enhance its IT expertise $[13,19,29]$. However, due to the nature of the board of directors at the university, there are not many options to thoughtfully alter its composition. When the University of Antwerp initiated more board level engagement in digital strategy and oversight, only 6 of the 25 members of the board were external directors. The internal directors were appointed after elections among the different university entities and students. From the 6 external members, the university could merely appoint 3 . The others were selected by the minister for education, the governor of the province of Antwerp and the provincial superior of the society of Jesus, which made it difficult to increase the level of IT expertise among board members. Since September $1^{\text {st }} 2017$, the board is allowed to appoint 3 additional directors. This change will provide the university with the opportunity to slightly alter the composition of the board. As the 3 additional members have not been appointed yet at the time of writing, the future will show whether this new arrangement will result in a higher level of IT expertise at the board of directors.

Due to the limited level of IT expertise on the board, it makes sense to make sure this IT expertise is 
present and IT-related debates are held in other structures that report to or advise the board. Accordingly, committees were created that include board members and that assist the board in IT-related decision making and control. Indeed, the creation of an IT oversight or similar committee at board level is a frequently mentioned approach in academic literature to increase board involvement in IT governance [8, 17, 26]. At the university, two such committees were created. One committee, the IT governance committee, considers rather short term decisions and is in charge of portfolio management of IT enabled investments. This committee is supported by the investment office. The other committee, the digital strategy think tank, considers the long term from more an outside-in perspective. The committees are presented in Figure 1.

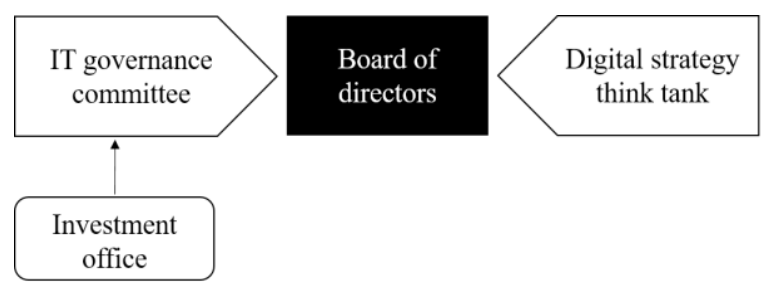

Figure 1 IT oversight committees at the University of Antwerp

5.2.1. Guiding principles. When the University of Antwerp decided to act on the growing need for IT governance mechanisms, a set of guiding principles was agreed upon. These principles include:

1. Transparency regarding investment criteria: the evaluation of proposed investments should be handled in a transparent way. Clear criteria should be created to decide whether or not to start an investment.

2. Transparency regarding the investment budget: the size of the investment budget should be known at all times.

3. Transparency regarding individual investments: for every investment a business case needs to be developed according to a standard form. Moreover, a business owner is appointed to each investment and no investments can be launched without a business owner.

4. Transparency regarding the investment portfolio: all investments need to go through the same portfolio decision cycle so that a full and transparent view can be obtained.

These guiding principles were used as a basis to create the board level IT governance structures that are described in the following sections.
5.2.2. IT governance committee. The IT governance committee was established in 2015 and meets 3 times a year. The main goal of this committee is to manage the IT enabled investment portfolio more effectively and transparently and make sure it is in line with the overall organization strategy. From a board's perspective, the committee should provide reasonable assurance that the university's IT enabled investments are in line with the university strategy. Indeed, up until now, the main topic of the committee meetings has been which investments to execute. However, the interviewees indicated that in the future, other topics like project benefits delivery and the IT policy plan could be part of this meeting.

Not all IT enabled investments pass by the IT governance committee. Rather operational investments - like the renewal of certain academic software licenses - are not discussed at this level of the organization, as these would overburden this forum. Instead, the committee focuses on more strategic and innovative projects, which cover about $45 \%$ of the entire IT budget.

Due to the democratic nature of the decision making culture at the university, it is crucial to include a broad delegation of people of the university in this committee. Hence, the goal was to create an entity that would represent all university entities as good as possible. The result is a committee that consists of 15 voting members and 30 advisory members. In addition, the chairman and vicechairman can invite internal or external experts that act as advisors. The rector is appointed chairman, the chair of the board of administration is the vicechairman. The 15 voting members are the rector, 2 members of the Board of Administration, the 4 vicerectors, 3 members of the board of directors, 3 members appointed by the Council of Deans and the 2 heads of the IT department.

The composition reveals that the board is actively engaged in the IT debate. Four directors were appointed voting members of the IT governance committee (including the rector) and all other directors are also welcome to join. Indeed, at the past committee meetings, attendance ranged from 4 up to 8 directors.

As the heads of the IT department are included in the committee, a certain level of IT expertise is present. However, the goal of the committee is not to go too much into the technical details, but to discuss the investments from a business perspective. Indeed, one of the heads of the IT departments states: "Within the IT governance committee we present the projects as understandable and as little technical as possible. This is also explicitly mentioned in the IT governance committee charter." Of course, the 
details must be considered at one point. Therefore, it was decided to establish an additional preparatory committee; the investment office.

The investment office is responsible for preparing investments to be presented to the IT governance committee. More specifically, a scoring model, which is approved by the IT governance committee, is used to evaluate the fit with the organization strategy, the risks and the expenditure. This scoring model enables a fairly objective quotation of the investment. Investments are evaluated from a business as well as a technical perspective. For example, the match with the three core tasks of the university (education, research and services) is assessed. An overview of all the scoring criteria is shown in Table 2.

Table 2 Scoring model

\begin{tabular}{|l|l|}
\hline \multirow{4}{*}{ Domain } & Criterion \\
\cline { 2 - 2 } Business & Strategic match domain education \\
\cline { 2 - 2 } domain & Strategic match domain research \\
\cline { 2 - 2 } & Strategic match domain services \\
\cline { 2 - 2 } & Administrative streamlining \\
\cline { 2 - 2 } & Management information \\
\cline { 2 - 2 } & Marketing / image \\
\cline { 2 - 2 } Technology & Strategic match ICT policy plan \\
\hline \multirow{4}{*}{ domain } & Strategic IS architecture \\
\cline { 2 - 2 } & Definitional uncertainty \\
\cline { 2 - 2 } & Technical uncertainty \\
\cline { 2 - 2 } & IS infrastructure risk \\
\hline
\end{tabular}

For each of these criteria, underlying questions were developed that allow to come to a "green", "yellow" or "red" score in a consistent way. Green represents a good match, yellow exemplifies a limited match and red suggests there is no match. In case the investment criterion is not applicable (e.g. an investment in a new online platform for research is not relevant for the education strategy) a "grey" score is used. At the end of this exercise, a scorecard is created, showing the benefits, risks and expenditure of each investment. The scores are presented using colors, as this enables the reader to evaluate the investment's strengths and weaknesses at a glance.

The investment office does not make any investment decisions but can conclude that a proposed investment is not yet fully defined and matured in the current business case document. As this is merely a supporting committee with a more indepth focus, it does not reside at the level of the board. The actual decision on whether or not to go through with an investment is made in the IT governance committee. However, the score determined by the investment office is crucial to make this decision. This is reflected in the IT governance committee agenda, which always includes the topics as shown in Table 3.

Every meeting, an overview of the IT budget is provided, which is in line with the guiding principles regarding transparency that were established at the beginning of this venture. Furthermore, all investments in need of a go/no-go decision are discussed. First, the investment business case and the color code that is determined by the investment office are presented. Then, the committee discusses the investment. Lastly, it is decided whether or not the investment will be executed.

\section{Table 3 IT governance committee agenda - main topics}

IT governance committee agenda

Budget overview

Investments:

- Investment business case

- Color code resulting from scoring model

- Discussion

- Decision

5.2.3. Digital strategy think tank. The other IT governance structure at the top-level of the university is the digital strategy think tank. The current rector started his term in 2016. From the beginning of his mandate, he stated he wants "an organization that is agile and thinks about future needs" and in support of that, he wants to free up the time of the board to execute this task. He argues that "IT is no longer a supporting frame, it is much more than that. We are at the beginning of an evolution and do not even realize what is in front of us. We need to think about the university in 20 years, IT in 20 years and the society in 20 years."

In light of these developments, he initiated the creation of the digital strategy think tank which meets several times a year (the meeting frequency is currently undefined, in 2017 four meetings took place).

The goal of this committee is to consider long term developments that could influence the university. They consider both how emerging technologies can impact the university's business model and strategy, as well as how challenges in society and markets could be addressed levering new technological innovations. One of the topics discussed was the fact that at a certain point in the future, more people will retire than enter the job market, which might trigger companies to hire students before they have finished their masters. This development could affect the university, as it might require students to obtain their master's degree in a more flexible way, for example supported by e- 
learning. These kind of digital strategy discussions require a certain level of IT expertise, which is reflected in the composition of the committee. The members of the digital strategy think tank are the rector, the chair of the Board of Administration, 3 professors with IT expertise, a board member with IT expertise and 4 members of the IT department.

Similar to the IT governance committee, the board of directors is represented in the think tank; the rector and one other board member are included. The difference is that for the digital strategy think tank, they specifically opted to include a board member with IT expertise.

Table 4 provides an overview of the two IT oversight committees at the University of Antwerp, their goal and members.

\section{Table 4 Overview IT oversight committees at the University of Antwerp}

\begin{tabular}{|c|c|c|}
\hline Committee & Goal & Members \\
\hline $\begin{array}{l}\text { IT } \\
\text { governance } \\
\text { committee }\end{array}$ & $\begin{array}{l}\text { Manage IT } \\
\text { enabled } \\
\text { investment } \\
\text { portfolio more } \\
\text { effectively and } \\
\text { transparently and } \\
\text { align it with } \\
\text { overall } \\
\text { organization } \\
\text { strategy. }\end{array}$ & $\begin{array}{l}\text { - Rector } \\
\text { - } 2 \text { Members of the } \\
\text { Board of } \\
\text { Administration } \\
\text { - The } 4 \text { vice-rectors } \\
\text { - } 3 \text { Members of the } \\
\text { board of directors } \\
\text { - } 3 \text { Members } \\
\text { appointed by the } \\
\text { Council of Deans } \\
\text { - } 2 \text { Heads of the IT } \\
\text { department }\end{array}$ \\
\hline $\begin{array}{l}\text { Digital } \\
\text { strategy } \\
\text { think tank }\end{array}$ & $\begin{array}{l}\text { Keep an eye on } \\
\text { the impact of } \\
\text { technological } \\
\text { developments on } \\
\text { the university and } \\
\text { consider how } \\
\text { societal and } \\
\text { market challenges } \\
\text { could be addressed } \\
\text { leveraging } \\
\text { technology. }\end{array}$ & $\begin{array}{l}\text { - Rector } \\
\text { - Chair of the } \\
\text { Board of } \\
\text { Administration } \\
\text { - } 3 \text { professors with } \\
\text { IT expertise } \\
\text { - A board member } \\
\text { with IT expertise } \\
\text { - } 4 \text { members of the } \\
\text { IT department }\end{array}$ \\
\hline
\end{tabular}

\section{Discussion}

This study on the board level IT governance committees at the University of Antwerp provides some unique insights with regard to the two research questions that contribute to the body of knowledge of board level IT governance research which are presented in this section.

No consensus seems to exist on the role of an IT oversight committee at the level of the board of directors. The roles described in literature are (1) monitoring of competitors and other organizations with regard to their IT-related activities [17], (2) monitoring of IT project costs and benefits, risk and compliance and value delivery [18], (3) ensuring IT is a topic on the board agenda and (4) ensuring boards have the necessary information for IT decision-making [21]. The case of the University of Antwerp indicates that the role of the committee strongly depends on the needs of the organization. This is in line with the guidance provided in literature, which incorporates a contingency approach. Yet, current research focusses on the contingency factors that determine whether or not an organization should install an IT oversight or similar committee. Yet, this case study suggests that a contingency approach can also be taken towards the role of such a committee. At the University of Antwerp, the role of the IT governance committee corresponds to the role described by Oliver and Walker [18]. That is, this committee is mainly responsible for the evaluation of the business cases of IT-related projects. Yet, the role of the digital strategy think tank is different from the roles described in academic literature. This committee's responsibility is to keep an eye on the impact of technological developments on the university and consider how societal and market challenges could be addressed leveraging technology. Hence, it seems that the list of roles described in literature is not exhaustive. Thus, defining the possible roles of IT oversight committees is an interesting topic for future research.

As previously mentioned, various theoretical perspectives are applied to examine board level IT governance, implying different board roles: control, service and resource dependence. This case study also demonstrates how the board of directors could execute these roles through IT oversight committees.

The control role of the board with regard to IT governance, based on agency theory, entails that the board should monitor the IT-related actions and decisions of management $[20,25]$. In order to adequately perform this control role, board members should have the right competencies to challenge the responses of management, which is often not the case $[20,25,29,31]$. Moreover, the information asymmetry between the board and management should be reduced to a minimum [31]. At the University of Antwerp, the control role is mainly assigned to the IT governance committee. The problems of limited IT-related knowledge and information asymmetry are coped with through the support of the investment office. The investment office ensures that the necessary information reaches the IT governance committee. On top of that, they prepare decisions by evaluating investments using a 
scoring model, which was approved by the IT governance committee. IT expertise is necessary to fill in this scoring model, but not to use the results. That way, the IT governance committee can adequately perform its control role, regardless of its limited IT expertise.

Stewardship theory implies that the board also has a service role, which entails duties like advising management on matters such as IT strategy, helping them fund strategic opportunities and responding to management requests [26, 27]. In the case of the university, the digital strategy think tank is entirely focused on this board responsibility. More specifically, this committee provides guidance to management on IT strategic opportunities and challenges.

Various authors have presented the resourcebased view of the firm and the resource dependence theory as perspectives to examine board level IT governance [26, 28, 31], suggesting that board members can be valuable resources for the governance of IT. This case study demonstrates this board member value and the potential role of a committee to unfold or even maximize it. Due to the nature of the selection process of board members at the university of Antwerp, it is very difficult to deliberately balance the expertise within the board. Yet, the university was able to select one nonexecutive director with significant IT expertise. The impact of this one director has increased considerably with the creation of the digital strategy think tank. This smaller committee offers a perfect platform for this director to have a substantial impact and deliver value by adding an outside perspective and significant IT expertise. Because of this platform that was designed to hold discussions regarding long term IT developments, the value that this IT savvy director can deliver is maximized.

This study also provides some insights on possible IT oversight committee arrangements. Current research suggests the establishment of one IT oversight (or similar) committee, in some cases supported by the audit or risk committee. Nevertheless, the university decided to create two IT oversight committees at the level of the board. Although this is in conflict with existing guidance, it is an interesting approach as it allows the organization to clearly separate different responsibilities and adapt committee membership accordingly. In this specific case, the responsibilities of portfolio management on the one hand and a ensuring forward-looking, outside-in approach on the other hand are divided over two committees. For the former, the efficient management of the IT-enabled investment portfolio, the university needed representatives of both business and IT. Furthermore, it was crucial to include a broad delegation of members, covering a wide range of university entities. However, the membership needs of the digital strategy think tank are entirely different. Here, a certain level of IT expertise is crucial as well as the competence to think about long term strategies. That is why for instance a non-executive director with significant IT expertise is included. Moreover, the type of discussions held at this committee requires a smaller amount of members.

\section{Limitations and future research}

Several limitations should be acknowledged. First, a single case study is described. It might be interesting to be able to examine multiple organizations and compare various IT oversight committee arrangements. However, a single case enabled us to describe the context and features of the IT oversight committees at the university in detail.

Second, the University of Antwerp is still at the beginning of its board level IT governance journey. Future research should also include studies of organizations with more mature board level IT governance arrangements.

This case study provides various new insights on IT oversight committees at the level of the board that could spark additional research. First, the summary of existing literature on this topic reveals that different roles of IT oversight committees are described by different authors. In addition, this case study suggests an additional role that was not yet mentioned in academic literature. Defining the various roles a committee could take up might enable us to create a better understanding of how such a committee could be a valuable asset and, as a consequence, stimulate board members to establish this kind of structure.

Second, we provide an example of how a board level committee, in this case the IT governance committee, is supported by a committee at another level in the organization, i.e. the investment office. The cooperation of committees at different levels in the organization deserves more attention. More broadly speaking, the dynamics between governance mechanisms at the level of the board and at lower levels is a crucial research topic. Indeed, a holistic approach towards IT governance is essential [11]. Furthermore, the dynamics between executive management and the board of directors has been a well-researched topic within corporate governance research [1, 2, 23, 24]. Similarly, we should not consider board IT governance mechanisms in a 
vacuum, but examine their relationship to the governance system in the rest of the organization.

Third, this case study suggests that the modus operandi of an IT oversight committee highly depends on the role it assumes. Consequently, future research should examine different committee arrangements and how they relate to the committee role.

Fourth, in this research we examine how boards of directors can operationalize their IT governance duties, but what about reporting on this topic? As research indicates that board level IT governance leads to increased organizational performance [13, 26] and theories such as voluntary disclosure theory and agency theory predict that firms can improve their liquidity and firm valuation through better information intermediation [12], organizations could benefit from IT governance disclosure [15]. As a consequence, how boards report on their involvement in IT governance could be an interesting topic for future research.

\section{Conclusion}

The goal of this research was to open up the black box of IT oversight (or similar) committees at the level of the board of directors. More specifically, we used a case study to provide insights on the role and modus operandi of such committees. We concluded that an IT oversight committee can take up various roles, depending on the organization's needs. Furthermore, the board can execute its control, service and resource dependence roles through such a committee. The case study also provided inspiration with regard to the workings of an IT oversight committee. That is, the board can establish multiple committees in order to separate responsibilities. Clearly, membership should be adapted according to the responsibilities the committee assumes.

With this research, we contribute to the IT governance knowledge base in several ways. First, we found that both researchers and practitioners agree that boards of directors can no longer delegate their IT governance related responsibilities, yet, few boards engage in governing IT. We contribute to closing this knowing doing gap by focusing on the most frequently mentioned guideline in academic research.

Second, none of the existing research on board level IT governance reports on governance practices observed in a specific organization in detail. Instead, descriptive research regarding this topic currently includes reports of large data sets containing information on the mechanisms deployed and perceptions of board members resulting from surveys and interview with individual board members. With regard to research on IT oversight committees at the level of the board, we found only few studies that report on the current state of practice. These studies simply report on the presence of an IT oversight committee and provide some quotes of board members expressing their opinion on the need for such a committee $[7,13,17]$. Hence, this is the first in-depth study on IT oversight committees, providing the details and context of this governance mechanism in a specific organization.

Third, because we are the first to take an in-depth look at IT oversight committees, many new and interesting paths for future research surface.

We contribute to practice by inspiring boards and board members who are attempting to increase their engagement in IT governance. Especially those boards with a limited amount of IT expertise. While enhancing the IT expertise within the board is a popular, and probably the most obvious, strategy to increase and improve the involvement of the board in IT governance, it can be very difficult. An alternative way to get started is creating an IT oversight committee, involving people with IT expertise from different layers of the organization. Moreover, an IT oversight committee ensures the involvement of the board in the IT debate. We provide boards with clear and applicable guidance on the possible organization and role of such an IT oversight committee.

\section{References}

[1] Adams, R.B. and D. Ferreira, A theory of friendly boards. The Journal of Finance, 2007. 62(1): p. 217-250.

[2] Adams, R.B., B.E. Hermalin, and M.S. Weisbach, The role of boards of directors in corporate governance: $A$ conceptual framework and survey. Journal of Economic Literature, 2010. 48(1): p. 58-107.

[3] Andriole, S.J., Boards of directors and technology governance: The surprising state of the practice. Communications of the Association for Information Systems, 2009. 24(1): p. 22.

[4] Bart, C. and O. Turel, IT and the board of directors: An empirical investigation into the "governance questions" Canadian board members ask about IT. Journal of Information Systems, 2010. 24(2): p. 147-172.

[5] Best, P. and S. Buckby. Development of a Board IT Governance (ITG) Review Model. in 2007 Accounting \& Finance Association of Australia and New Zealand Conference (AFAANZ 2007). 2007. 
[6] Brown, A.E. and G.G. Grant, Framing the frameworks: A review of IT governance research. Communications of the Association for Information Systems, 2005. 15(1): p. 38 .

[7] Coertze, J. and R. Von Solms, The Board and IT Governance: A Replicative Study. African Journal of Business Management, 2013. 7(36): p. 3358.

[8] Coertze, J. and R. von Solms, The Board and CIO: The IT Alignment Challenge, in 2014 47th Hawaii International Conference on System Sciences, R.H. Sprague, Editor. 2014. p. 4426-4435.

[9] Coertze, J. and R. von Solms. The murky waters of IT governance. in Information Security for South Africa (ISSA), 2014. 2014. IEEE.

[10] De Haes, S. and W. Van Grembergen, An Exploratory Study into IT Governance Implementations and its Impact on Business/IT Alignment. Information Systems Management, 2009. 26(2): p. 123-137.

[11] De Haes, S. and W. Van Grembergen, Enterprise governance of information technology. 2015: Springer.

[12] Healy, P.M. and K.G. Palepu, Information asymmetry, corporate disclosure, and the capital markets: A review of the empirical disclosure literature. Journal of Accounting \& Economics, 2001. 31(1-3): p. 405-440.

[13] Jewer, J. and K.N. McKay, Antecedents and Consequences of Board IT Governance: Institutional and Strategic Choice Perspectives. Journal of the Association for Information Systems, 2012. 13(7): p. 581-617.

[14] Johnson, J.L., C.M. Daily, and A.E. Ellstrand, Boards of directors: A review and research agenda. Journal of management, 1996. 22(3): p. 409-438.

[15] Joshi, A., et al., Explaining IT governance disclosure through the constructs of IT governance maturity and IT strategic role. Information \& Management, 2017.

[16] Mähring, M., The role of the board of directors in IT governance: A review and agenda for research. AMCIS 2006 Proceedings, 2006: p. 377.

[17] Nolan, R. and F.W. McFarlan, Information technology and the board of directors. Harvard Business Review, 2005. 83(10): p. 96-+.

[18] Oliver, G.R. and R.G. Walker, Reporting on software development projects to senior managers and the board. Abacus-a Journal of Accounting Finance and Business Studies, 2006. 42(1): p. 43-65.

[19] Parent, M. and B.H. Reich, Governing Information Technology Risk. California Management Review, 2009.
51(3): p. 134-+.[20] Posthumus, S. and R. von Solms, Agency theory: Can it be used to strengthen IT governance? Proceedings of the Ifip Tc 11/ 23rd International Information Security Conference, ed. S. Jajodia, P. Samarati, and S. Cimato. 2008. 687-691.

[21] Posthumus, S., R. von Solms, and M. King, The board and IT governance: The what, who and how. South African Journal of Business Management, 2010. 41(3): p. 23-32.

[22] Read, T.J., Discussion of director responsibility for IT governance. International journal of accounting information systems, 2004. 5(2): p. 105-107.

[23] Song, F. and A.V. Thakor, Information control, career concerns, and corporate governance. The Journal of Finance, 2006. 61(4): p. 1845-1896.

[24] Sundaramurthy, C. and M. Lewis, Control and collaboration: Paradoxes of governance. Academy of management review, 2003. 28(3): p. 397-415.

[25] Trites, G., Director responsibility for IT governance. International Journal of Accounting Information Systems, 2004. 5(2): p. 89-99.

[26] Turel, O. and C. Bart, Board-level IT governance and organizational performance. European Journal of Information Systems, 2014. 23(2): p. 223-239.

[27] Turel, O., P. Liu, and C. Bart, Board-Level Information Technology Governance Effects on Organizational Performance: the Roles of Strategic Alignment and Authoritarian Governance Style. Information Systems Management, 2017: p. null-null.

[28] Valentine, E. and G. Stewart. Director competencies for effective enterprise technology governance. in Proceedings of the 24th Australasian Conference on Information Systems (ACIS 2013). 2013.

[29] Valentine, E. and G. Stewart, Enterprise Business Technology Governance: Three Competencies to Build Board Digital Leadership Capability, in 2015 48th Hawaii International Conference on System Sciences, T.X. Bui and R.H. Sprague, Editors. 2015. p. 4513-4522.

[30] Wilkin, C.L. and R.H. Chenhall, A review of IT governance: A taxonomy to inform accounting information systems. Journal of Information Systems, 2010. 24(2): p. 107-146.

[31] Yayla, A.A. and Q. Hu, The effect of Board of directors' IT awareness on CIO compensation and firm performance. Decision Sciences, 2014. 45(3): p. 401-436.

[32] Yin, R.K., Case study research: Design and methods. 2013: Sage publications. 